\title{
Effects of Various Cooking Methods on Quality Characteristics of Korean Boiled Pork (Soo-yuk)
}

\author{
Young-Chul Chae and Cheon-Jei Kim* \\ Department of Food Science and Biotechnology of Animal Resources, Konkuk University, Seoul 143-701, Korea
}

\begin{abstract}
This research was conducted to evaluate the effects of cooking conditions on quality characteristics of Soo-Yuk, a traditional Korean food. The cooking conditions were as follows: boiled until the core temperature of a sample in $20^{\circ} \mathrm{C}$ cold water reached at $75^{\circ} \mathrm{C}(\mathrm{T} 1)$; boiled until the core temperature of a sample in $90^{\circ} \mathrm{C}$ boiling water reached at $75^{\circ} \mathrm{C}(\mathrm{T} 2)$; and boiled with sample from $20^{\circ} \mathrm{C}$ to $100^{\circ} \mathrm{C}$ and kept at $98^{\circ} \mathrm{C}$ for $25 \mathrm{~min}$ (T3, Korean traditional method). The sample cooked at $90^{\circ} \mathrm{C}$ water (T2) had the fast cooking time, and the highest cooking yield and moisture content. Soo-yuk boiled in $100^{\circ} \mathrm{C}$ water (T3) showed the longest cooking time, the lowest cooking yield and moisture content, and the highest shear force. The instrumental color showed a significant difference among the cooking conditions. The sarcomere length of soo-yuk boiled in $100^{\circ} \mathrm{C}$ water (T3) was the shortest, but the myofibrillar fragmentation index and thiamine content of the sample cooked at $90^{\circ} \mathrm{C}(\mathrm{T} 2)$ were the highest. In sensory evaluation, the evaluation of $s o o-y u k$ boiled in $98^{\circ} \mathrm{C}$ water (T3) was of superior flavor and overall acceptability.
\end{abstract}

Key words: soo-yuk, boiled pork loin, cooking method, eating quality

\section{Introduction}

Korean boiled pork, soo-yuk, is one of the popular foods in Korea. This cooking method tenderizes the texture of meat by dissociating connective tissue such as collagen and decrease a nutrient loss, especially vitamin $B_{1}$. Over the past few years, several studies have been made on boiled pork in Korea. Moon et al. (2001) reported that as the internal temperature of pork increased, cooking loss and hardness increased. Oh (1994) found that cooking loss increased in the studies of both conventional and microwave methods as heating temperature and power increased. Choi et al. (2006) improved quality properties of boiled pork loin using tumbling methods. Also, Park and Kwon (1998), and Jung et al. (2004) conducted the studies about the quality change of soo-yuk such as Korean boiled pork using bark (Morus alba Linne) and mugwort powder.

Abroad, there have conducted many researches on cooking conditions of meat. Many researchers conducted

\footnotetext{
*Corresponding author : Cheon-Jei Kim, Department of Food Science and Biotechnology of Animal Resources, Konkuk University, Seoul 143-701, Korea. Tel: 82-2-450-3684, Fax: 82-2-444-6695, E-mail: kimcj@konkuk.ac.kr
}

the studies about the effect of heating period to meat quality (Dube et al., 1972; Laakkonen et al., 1970; Machlik and Draudt, 1963). Forrest et al. (1975) recommended the appropriate temperatures: $77^{\circ} \mathrm{C}$ for end point for most fresh pork, 77 to $82^{\circ} \mathrm{C}$ for poultry, 58 to $60^{\circ} \mathrm{C}$ for rare beef, 66 to $68^{\circ} \mathrm{C}$ for medium rare, 73 to $75^{\circ} \mathrm{C}$ for medium and 80 to $82^{\circ} \mathrm{C}$ for well done. Steak and chop like tender cut are well matched with dry heat cooking methods for a short time. In case of meat cut with many connective tissue, the moist cooking method is suitable for braising for a long time at low temperature. Especially, Buck et al. (1979) found that pork roast had the best quality at internal temperature between $71.1^{\circ} \mathrm{C}$ and $76.7^{\circ} \mathrm{C}$ in the treatment that the oven at $21^{\circ} \mathrm{C}$ was roasted right after setting to $163^{\circ} \mathrm{C}$. Additionally, the research of Moss et al. (1983) on terms of heating methods for nutrient composition and Bower et al. (1987) on terms of heating temperature at 55 to $85^{\circ} \mathrm{C}$ for broiling at $290^{\circ} \mathrm{C}$ and roasting at $149^{\circ} \mathrm{C}$ said that the heating method was one of main factors that affect meat quality. Obuz et al. (2003) emphasized that we needs to monitor the temperature of all the cooking process to satisfy eating quality for consumers.

However, the food service industry still uses color or other visual observation methods to diagnose meat doneness and there has been no study about the cooking meth- 
ods of Korean boiled pork, soo-yuk. It is only the method that boils for a long time at $100^{\circ} \mathrm{C}$ with pork and cold water. Therefore, this study was conducted to improve the textural and sensorial quality of soo-yuk using various different cooking methods.

\section{Materials and Methods}

\section{Sample preparation}

Pork loin (M. longissimus dorsi) was purchased from a local processor at $48 \mathrm{~h}$ postmortem. All subcutaneous and intermuscular fat and visible connective tissue were removed from the fresh muscles, and then the pork loin was sliced at thickness of $2.5 \mathrm{~cm}$ and in the weight of $100 \pm 10 \mathrm{~g}$ and packed in Nylon/Polyethylene film at the temperature of $8 \pm 1^{\circ} \mathrm{C}$. The cooking conditions of samples are as follows (Fig. 1): boiled until reached to $75^{\circ} \mathrm{C}$ at core temperature with sample in $20^{\circ} \mathrm{C}$ cold water and immediately cooled for $30 \mathrm{~min}$ (T1); boiled until reached to $75^{\circ} \mathrm{C}$ at core temperature with sample in setting $90^{\circ} \mathrm{C}$ hot water and immediately cooled for $30 \mathrm{~min}$ (T2); and boiled with sample from $20^{\circ} \mathrm{C}$ to $100^{\circ} \mathrm{C}$ and held at $98^{\circ} \mathrm{C}$ for $25 \mathrm{~min}$ (T3, Korean traditional method). The change of internal temperature was measured, using a digital thermocouple (KM330, Kane-May, Germany). After cooking, the samples were taken from the water and cooled for $30 \mathrm{~min}$ at room temperature.

\section{Cooking yield}

The raw samples sliced in $2.5 \mathrm{~cm}$ thickness were boiled in three cooking conditions. After each cooked, samples were cooled for $30 \mathrm{~min}$ in the room temperature. The yield was calculated by the Eq. (1).

$$
\begin{aligned}
& \text { Cooking yield }(\%) \\
& =\text { Weight after cooking/Weight before cooking } \times 100
\end{aligned}
$$

\section{Moisture content}

The moisture content (\%) was determined by weight loss after $12 \mathrm{~h}$ of drying at $105^{\circ} \mathrm{C}$ in a drying oven (SW90D, Sang Woo Scientific Co., Bucheon, South Korea), using AOAC (2000) method.

\section{Shear force}

For the determination of shear force, samples were cooked individually in plastic bags immersed in a $75^{\circ} \mathrm{C}$ water bath for $30 \mathrm{~min}$. The cooked meats were cooled and sampled at room temperature using a $12.7 \mathrm{~mm}$ circular core to determine shear force. Four sample cores were sheared from each sample across the length of the core with a Warner-Bratzler shear attachment (V-type blade set) on the texture analyzer (TA-XT2 $i$, Stable Micro Systems, England) under cross head speed of $2 \mathrm{~mm} / \mathrm{sec}$. Texture Expert for the WINDOWS ${ }^{\mathrm{TM}}$ operation system was used to analyze the data. The shear force value was the
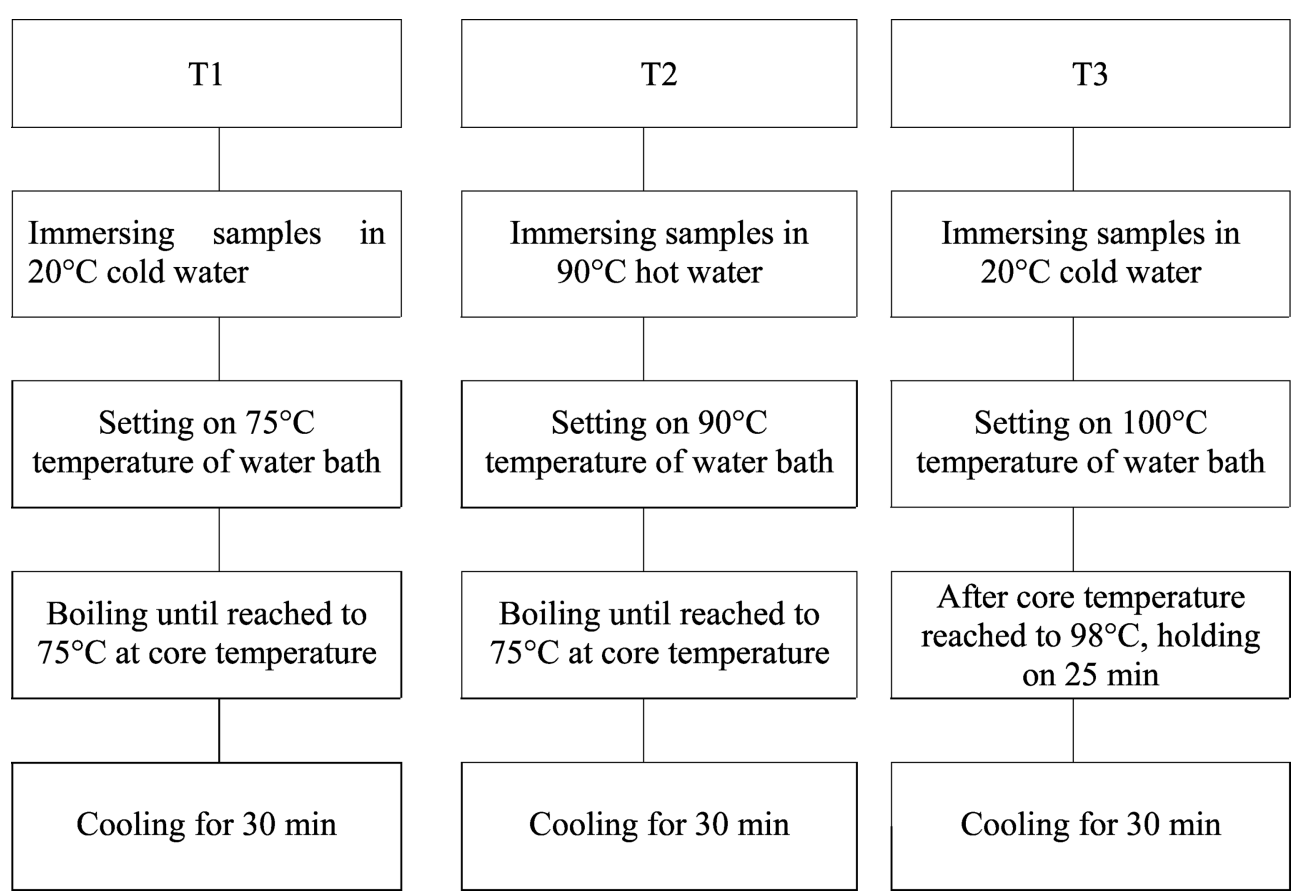

Fig. 1. Experimental design using various cooking conditions. 
mean of the maximum forces required to shear each set of core samples and the units used for shear force were kilograms $(\mathrm{kg})$.

\section{Instrumental color}

Color measurement were taken with color meter (Chroma meter, CR210, Minolta, Japan; illuminate C, calibrated with white standard palate $\mathrm{L}=97.83, \mathrm{a}=-0.43$ and $b=+1.98$ ). Color value were determined as indicator of lightness $\left(\mathrm{CIE} \mathrm{L}^{*}\right)$, redness $\left(\mathrm{CIE} \mathrm{a}^{*}\right)$, and yellowness (CIE b*) of sample.

\section{Sarcomere length}

Sarcomere length was determined by the method (Voyle, 1971) with Helium-Neon-Laser diffraction (Model No. 212-2, Spectra-physics, USA). At different time postmortem, 1-2 g of muscle samples were carefully cut with a knife and immersed in $2 \%$ glutaraldehyde solution with $2 \%$ glucose in a $0.1 \mathrm{M}$ phosphate buffer, $\mathrm{pH} 7.0$, at temperature similar to that at which the muscles were incubated, and sarcomere length was measured.

\section{Myofibrillar fragmentation index (MFI)}

Myofibrils were obtained according to the method of Olson et al. (1976a) using the MFI buffer $(20 \mathrm{mM}$ $\mathrm{K}_{2} \mathrm{HPO}_{4} / \mathrm{KH}_{2} \mathrm{PO}_{4}, \mathrm{pH} 7,100 \mathrm{mM} \mathrm{KCl}, 1 \mathrm{mM}$ EDTA, 1 $\mathrm{mM} \mathrm{NaN}{ }_{3}$ ). The myofibrils were suspended in MFI buffer. An aliquot of myofibril suspension was diluted with the MFI buffer to $0.5 \mathrm{mg} / \mathrm{mL}$ protein concentration and the absorbance of this suspension was measured at $540 \mathrm{~nm}$. MFI values were recorded as absorbance units per $0.5 \mathrm{mg} / \mathrm{mL}$ myofibril protein concentration multiplied by 200 .

\section{Thiamin content}

Five g of sample and $0.1 \mathrm{~N} 50 \mathrm{~mL}$ of $\mathrm{HCl}$ was boiled in hot plate at $70-80^{\circ} \mathrm{C}$ for $1 \mathrm{~h}$ and cooled. Subsequently, the samples were cooled to ambient temperature, and the sample volume was brought up to $50 \mathrm{~mL}$ with water before centrifugation at $3000 \mathrm{rpm}$ for $5 \mathrm{~min}$. The $5 \mathrm{~mL}$ supernatant was mixed with $2.5 \mathrm{~mL}$ potassium ferricyanide in $15 \%$ sodium hydroxide, and mixed for $10 \mathrm{~s}$ to ensure derivatisation of thiamine to thiochrome. Subsequently, the derivatisation solution was brought up to 10 $\mathrm{mL}$ with $3.75 \mathrm{M} \mathrm{HCl}$ before sample clean-up with $\mathrm{C} 18$ solid phase extraction columns and analysis of thiochrome. HPLC used Waters 486 Tunable Absorbance Detector, Waters M510 Pump for Waters 717Plus Autosampler (USA). The condition of separation was mobile phase $(5 \mathrm{mmol} / \mathrm{L}$ sodium hexanesulfonate, $20 \mathrm{mmol} / \mathrm{L}$ $\mathrm{H}_{2} \mathrm{PO}$ ) $/ \mathrm{CH}_{2} \mathrm{CN}=91 / 9$, column (Waters Atlantis $\mathrm{C}_{18}$, $5 \mathrm{UM}$, id $4.6 \mathrm{~mm} \times 150 \mathrm{~mm}$ ) with $1 \mathrm{~mL} / \mathrm{min}$ of flow rate, absorbance $(210 \mathrm{~nm})$ and $10 \mu \mathrm{L}$ of input.

\section{Sensory evaluation}

Uniformed dimensions of sample $(1 \mathrm{~cm} \times 1 \mathrm{~cm} \times 0.2 \mathrm{~cm})$ were used for the sample for sensory evaluation. Cooked samples were served to 12 experienced panel members with previous experience. Panelists were presented with three randomly coded samples. The color $(1=$ extremely undesirable, $10=$ extremely desirable), flavor ( $1=$ extremely undesirable, $10=$ extremely desirable $)$, tenderness $(1=$ extremely tough, $10=$ extremely tender), juiciness ( $1=$ extremely dry, $10=$ extremely juicy), and overall acceptability (1=extremely undesirable, $10=$ extremely desirable) of the cooked samples were evaluated using a 10-point descriptive scale. Sliced samples served at a temperature of approximately room temperature to each panelist. Warm water $\left(30^{\circ} \mathrm{C}\right)$ was given to panelists to consume between samples.

\section{Statistical analyses}

An analysis of variance were performed on all the variables measured using the General Linear Model (GLM) procedure of the SAS statistical package (1996). The Duncan's multiple range test $(p<0.05)$ was used to determine differences between treatment means.

\section{Results and Discussion}

\section{Time-temperature profile and cooking yield}

The time-temperature profile and cooking yield of boiled pork loins (soo-yuk) cooked with various cooking

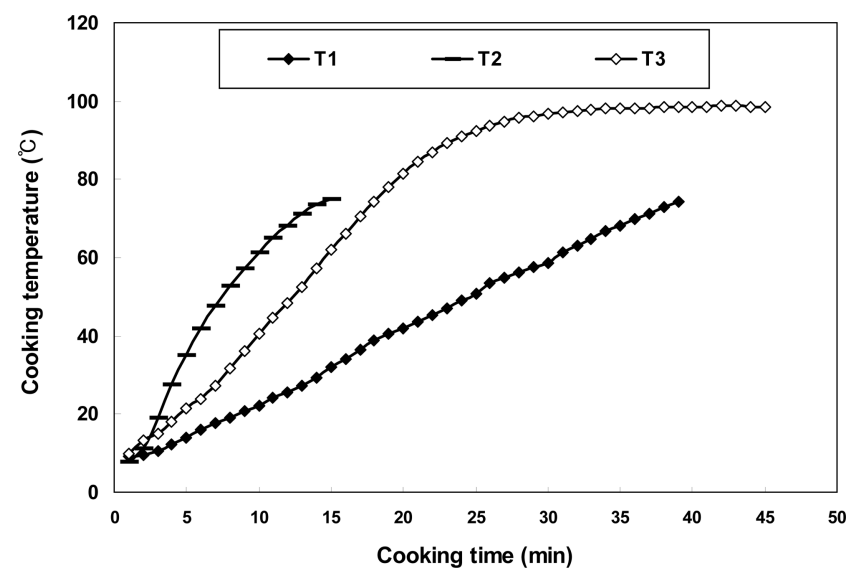

Fig. 2. The time-temperature profile of boiled pork loins (soo-yuk) cooked with various cooking conditions. 
Table 1. Comparison on cooking yield, moisture content, and instrumental color of boiled pork loins (soo-yuk) cooked with different cooking conditions

\begin{tabular}{|c|c|c|c|c|}
\hline \multirow{2}{*}{\multicolumn{2}{|c|}{ Traits }} & \multicolumn{3}{|c|}{ Cooking condition ${ }^{1)}$} \\
\hline & & $\mathrm{T} 1$ & $\mathrm{~T} 2$ & $\mathrm{~T} 3$ \\
\hline \multicolumn{2}{|c|}{ Cooking yield (\%) } & $66.13 \pm 2.93^{\mathrm{b} 2)}$ & $67.88 \pm 3.54^{\mathrm{a}}$ & $56.03 \pm 3.10^{\mathrm{c}}$ \\
\hline \multicolumn{2}{|c|}{ Moisture content (\%) } & $62.68 \pm 1.28^{\mathrm{b}}$ & $64.34 \pm 1.86^{\mathrm{a}}$ & $58.79 \pm 1.38^{\mathrm{c}}$ \\
\hline \multirow{3}{*}{ Color } & CIE L* & $67.03 \pm 2.02^{\mathrm{b}}$ & $69.42 \pm 1.76^{\mathrm{a}}$ & $66.99 \pm 2.04^{\mathrm{b}}$ \\
\hline & CIE a* & $4.70 \pm 0.84^{\mathrm{a}}$ & $4.17 \pm 0.81^{\mathrm{b}}$ & $3.24 \pm 0.80^{c}$ \\
\hline & CIE $b^{*}$ & $8.38 \pm 0.93^{b}$ & $7.38 \pm 0.52^{\mathrm{c}}$ & $9.56 \pm 0.53^{\mathrm{a}}$ \\
\hline
\end{tabular}

${ }^{1)}$ Cooking conditions are presented in Fig. 1 .

${ }^{2)}$ All values are mean $\pm \mathrm{SD}$.

${ }^{\mathrm{a}-\mathrm{c}}$ Means values with different superscripts within a same row are significantly different $(p<0.05)$.

conditions are shown in Fig. 2 and Table 1, respectively. $\mathrm{T} 2$ treatment that started heating from hot water $\left(4.46^{\circ} \mathrm{C} /\right.$ min) showed a faster cooking rate than $\mathrm{T} 1$ treatment that started heating from cold water $\left(1.7^{\circ} \mathrm{C} / \mathrm{min}\right)$ and $\mathrm{T} 3$ treatment by the conventional method $\left(3.72^{\circ} \mathrm{C} / \mathrm{min}\right)$. $\mathrm{T} 2$ treatment reached internal temperature of $75^{\circ} \mathrm{C}$ in the shortest time due to boiling at $90^{\circ} \mathrm{C}$ water and its cooking yield was significantly higher than other treatments due to the short cooking time. T1 treatment took $40 \mathrm{~min}$ to reach $75^{\circ} \mathrm{C}$, showing the longest cooking time. The cooking yield of T3 treatment was the lowest because of its high temperature and long cooking time $(p<0.05)$. T2 treatment took $15 \mathrm{~min}$ to reach at $75^{\circ} \mathrm{C}$ in internal temperature and resulted in a cooking yield of $67 \%$. The result was similar to the study of Choi et al. (2006), in which the core temperature reached at $75^{\circ} \mathrm{C}$ in $14 \mathrm{~min}$ and the cooking yield was about 65\%. Also, Pan and Singh (2001) reported that cooking loss increased and the cooking yield decreased as cooking temperature increased, and Barbanti and Pasquini (2005) indicated that the cooking yield increased as cooking time decreased.

\section{Moisture content and instrumental color}

Table 1 shows the moisture content of boiled pork loins (soo-yuk) cooked with different cooking conditions. T3 treatment had a lower moisture content than other treatments due to its high temperature and long cooking time $(p<0.05)$. On the contrary, T2 treatment had the highest moisture content because of short cooking time $(p<0.05)$. This result agrees with the report of Lawrie (1988) that increasing heating velocity leads to less cooking loss and more juiciness, and are consistent with the results of a study on the moisture content by Bengtsson et al. (1976). Godsalve (1977) indicated that, in the process of various heating temperature and time, heating temperature influenced more in moisture content than time. On the other hand, Pietrasik and Shand (2003) found that cooking loss affected the moisture content of the meat as well as its tenderness. The result of this study is similar with their result.

The instrumental color of soo-yuk cooked with different cooking conditions was shown in Table 1. T2 treatment with high heating temperature indicated the highest value of CIE-L (lightness) and no significant difference was observed between T1 and T3 ( $p>0.05)$. T1 treatment with a fast cooking rate had the highest CIE $\mathrm{a}^{*}$ (redness) and T3 treatment boiled at high temperature and for a long time showed the lowest. In CIE b* (yellowness) value, T3 treatment was the highest and $\mathrm{T} 2$ treatment was lowest.

\section{Shear force, sarcomere length, and MFI}

The shear force and sarcomere length of boiled pork loin cooked with different cooking conditions are shown in Table 2. T3 treatment showed the highest shear force with the lowest cooking yield, but there was not a significant difference between $\mathrm{T} 1$ and $\mathrm{T} 2$ treatments. This result is similar with the report of Choi et al. (2008) that cooking yield was negatively correlated with shear force. Also, Abugroun et al. (1985) found that fast heating $\left(2^{\circ} \mathrm{C} /\right.$ $2 \mathrm{~min}$ ) showed a lower shear force than slow heating $\left(2^{\circ} \mathrm{C} / 12 \mathrm{~min}\right)$ as indicated by the results of this experiment. With respect to Warner-Bratzer shear force (WBS), Belew et al. (2003) divided into most tender (WBS=2.03 $\mathrm{kg}$ ), very tender (WBS $<3.2 \mathrm{~kg}$ ), tender $(3.2 \mathrm{~kg}<\mathrm{WBS}<3.9$ $\mathrm{kg}$ ), intermediate $(3.9 \mathrm{~kg}<\mathrm{WBS}<4.6 \mathrm{~kg}$ ), tough (WBS $>$ $4.6 \mathrm{~kg}$ ) and toughest (WBS=7.7 kg). According to that standard, the shear force of the treated samples observed in this study were evaluated tender (T1, T2) and intermediate (T3), respectively.

In the changes of sarcomere length (Table 2), T3 treat-

Table 2. Comparison on shear force, sarcomere length, MFI, and thiamine content of boiled pork loins (soo-yuk) cooked with different cooking conditions

\begin{tabular}{|c|c|c|c|}
\hline \multirow{2}{*}{ Traits } & \multicolumn{3}{|c|}{ Cooking condition } \\
\hline & $\mathrm{T} 1$ & $\mathrm{~T} 2$ & T3 \\
\hline Shear force $(\mathrm{kg})$ & $35.68 \pm 6.47^{\mathrm{b} 2)}$ & $34.58 \pm 6.37^{b}$ & $40.80 \pm 7.45^{\mathrm{a}}$ \\
\hline Sarcomere length $(\mu \mathrm{m})$ & $1.53 \pm 0.08^{\mathrm{a}}$ & $1.45 \pm 0.06^{\mathrm{b}}$ & $1.30 \pm 0.09^{c}$ \\
\hline MFI & $57.96 \pm 4.70^{\mathrm{b}}$ & $66.35 \pm 4.82^{\mathrm{a}}$ & $57.04 \pm 3.81^{\mathrm{b}}$ \\
\hline Thiamine content $(\mathrm{mg} / \mathrm{kg})$ & $4.35 \pm 0.70^{a b}$ & $5.04 \pm 0.83^{\mathrm{a}}$ & $3.60 \pm 0.86^{\mathrm{b}}$ \\
\hline
\end{tabular}


ment heated for a long time and high temperature had the shortest sarcomere length, and T1 treatment that cooked slowly from low temperature showed a longer sarcomere length than other treatments $(p<0.05)$. Herring et al. (1965) found that the relationship between sarcomere length and meat tenderness was highly significant. In the present study, likewise, T3 treatment showed the highest shear force and the shortest sarcomere length. Dube et al. (1972) reported that the sarcomere shortening rate increased when heated the meat in a water bath at 60,70, 80 and $90^{\circ} \mathrm{C}$ for $30 \mathrm{~min}$. Bouton et al. (1975) observed the same result that the sarcomere length of calf decreased as temperature increased. Lewis and Purslow (1989) observed that sarcomere shrinkage did not happen until $60^{\circ} \mathrm{C}$, but $\mathrm{M}$-lines and I-bands of collagen fibers were disrupted and changed at the shrinkage temperature of $79^{\circ} \mathrm{C}$.

Generally, MFI is positively correlated with sensory and Warner-Bratzler measures of tenderness (Kim and Lee, 2003). MFI increases with longer postmortem aging times (Olson et al., 1976b) and is higher for younger maturity animals than for older maturities (Parrish et al., 1979). The MFI of boiled pork loin cooked with various cooking conditions is shown in Table 2. The pork loin (T2) cooked with the shortest cooking time in hot water showed higher MFI than those cooked in other conditions $(p<0.05)$. However, there was no significant difference in MFI between $\mathrm{T} 1$ and $\mathrm{T} 3$ treatments $(p>0.05)$. Tenderness of meat is in close connection with the MFI of sarcomere (Moller et al., 1973), and especially, the sample was considered very soft when the value of MFI was 60, and the sample with MFI below 50 was tough (Culler et al., 1978). In the present study, T2 treatment with lower shear force showed higher MFI than other treatments $(p<0.05)$.

\section{Thiamine contents}

Meat is a food source of vitamin B group like thiamine and riboflavin. Because thiamine is unstable at high temperature, cooking causes a much loss of thiamine (Leonhardt and Wenk, 1997). The thiamine content of boiled pork loin cooked with various cooking conditions is shown in Table 2. T1 and T2 treatments with low internal temperature $\left(75^{\circ} \mathrm{C}\right)$ did not show significant differences in thiamine contents, but $\mathrm{T} 3$ treatment cooked in $100^{\circ} \mathrm{C}$ water and heated at $98^{\circ} \mathrm{C}$ for $25 \mathrm{~min}$ had lower thiamine contents than $\mathrm{T} 2$ treatment $(p<0.05)$. In this result, the thiamine content of all the treatments ranged from 0.3 to 0.5 $\mathrm{mg} / 100 \mathrm{~g}$. Pearson and Dutson (1988) reported that pork had a thiamine content of $0.904 \mathrm{mg} / 100 \mathrm{~g}$ in lean tissue and $0.693 \mathrm{mg} / 100 \mathrm{~g}$ for roasted. Also, the thiamine content of raw pork loin changed from $0.60 \mathrm{mg} / 100 \mathrm{~g}$ to 0.15 $\mathrm{mg} / 100 \mathrm{~g}$ when heated in a $180^{\circ} \mathrm{C}$ oven for $30 \mathrm{~min}$ (Boccia et al., 2005). The thiamine content of $0.86 \mathrm{mg} / 100 \mathrm{~g}$ in pork loin was reduced to $40 \%$ by braising, $65 \%$ by broiling and $56 \%$ by roasting according to heating method (Moss et al., 1983). It is impossible to identify nutrient composition for all the prepared foods, but analytical and calculated data are fundamentally important to customers according to cooking method like boiling, steaming, braising, stewing, frying, roasting in oven and deep frying (Bognár and Piekarski, 2000).

\section{Sensory properties}

The results about the sensory characteristics of soo-yuk according to cooking condition were shown in Table 3. Color, tenderness, and juiciness were not significantly different among the treatments. However, T3 treatment cooked by the Korean traditional method obtained the highest score in flavor and overall acceptability. These results agreed with the report of Tajima et al. (2001) that flavor of beef heated for $3 \mathrm{~h}$ at $95^{\circ} \mathrm{C}$ was improved. Deethardt and Tuma (1971) reported that cooked pork loin using several different heating methods did not show significant differences in texture and flavor. Marsh et al. (1966) reported that tenderness decreased as shear force increased. However in the present study, tenderness was not significantly different among the treatments $(p>0.05)$. Also, Montgomery et al. (1977) reported that the panel score for juiciness, tenderness and overall acceptability did not show any difference when pork loin was heated in a microwave and a conventional oven at $63^{\circ} \mathrm{C}$ of internal temperature.

In conclusion, boiled pork loin (soo-yuk) cooked at

Table 3. Comparison on sensory characteristics of boiled pork loins (Soo-Yuk) cooked with different cooking conditions

\begin{tabular}{llll}
\hline \hline \multirow{2}{*}{ Traits } & \multicolumn{3}{c}{ Cooking condition $^{1)}$} \\
\cline { 2 - 4 } & \multicolumn{1}{c}{$\mathrm{T} 1$} & \multicolumn{1}{c}{$\mathrm{T} 2$} & $\mathrm{~T}$ \\
\hline Color $^{3}$ & $7.33 \pm 0.82$ & $7.33 \pm 0.92$ & $7.50 \pm 1.40$ \\
Flavor $^{3)}$ & $7.02 \pm 1.03^{\mathrm{b}}$ & $7.40 \pm 0.89^{\mathrm{b}}$ & $8.21 \pm 1.07^{\mathrm{a}}$ \\
Tenderness $_{\text {Juiciness }}$ & $7.25 \pm 1.11$ & $7.61 \pm 0.96$ & $7.65 \pm 1.30$ \\
Overall acceptability & $7.07 \pm 1.11^{\mathrm{c}}$ & $7.59 \pm 1.09^{\mathrm{b}}$ & $8.07 \pm 0.86^{\mathrm{a}}$ \\
\hline
\end{tabular}

${ }^{1)}$ Cooking conditions are presented in Fig. 1.

${ }^{2)}$ All values are mean $\pm \mathrm{SD}$.

${ }^{3)}$ Sensory scores were assessed on 10 point scale where $1=$ extremely bad or slight, $10=$ extremely good or much.

${ }^{\mathrm{a}-\mathrm{c}}$ Means values with different superscripts within a same row are significantly different $(p<0.05)$. 
$90^{\circ} \mathrm{C}$ hot water (T2) had excellent physicochemical properties such as cooking yields, moisture contents, and shear force. On the other hand, soo-yuk cooked at $98^{\circ} \mathrm{C}$ (T3) had better sensory properties such as flavor and overall acceptability. Because the quality characteristics of boiled pork loin change according to cooking conditions, more studies, therefore, are needed for establishing the cooking conditions of soo-yuk.

\section{References}

1. Abugroun, H. A., Forrest, J. C., Aberle, E. D., and Judge, M. D. (1985) Shortening and tenderness of prerigor heated beef. I. Effect of heating rate on muscle of youthful and mature carcasses. Meat Sci. 14, 1-13.

2. AOAC. (2000) Official Methods of Analysis. 17th ed, Association of Official Analytical Chemists, Washington, DC, chapter 39. pp. 1-8.

3. Barbanti, D. and Pasquini, M. (2005) Influence of cooking conditions on cooking loss and tenderness of raw and marinated chicken breast meat. J. Food Sci. Technol. 38, 895-901.

4. Belew, J. B., Brooks, J. C., Mckenna, D. R., and Savell, J. W. (2003) Warner-Bratzer shear evaluations of 40 bovine muscles. Meat Sci. 64, 507-512.

5. Bengtsson, N. E., Jakobsson, B., and Dagerskog, M. (1976) Cooking of beef oven roasting a study of heat and mass transfer. J. Food Sci. 41, 1047-1053.

6. Boccia, G. L., Lanzi, S., and Aguzzi, A. (2005) Aspects of meat quality: trace elements and $\mathrm{B}$ vitamins in raw and cooked meats. J. Food Compos. Anal. 18, 39-46.

7. Bognár, A. and Piekarski, J. (2000) Guidelines for recipe information and calculation of nutrient composition of prepared foods (dishes). J. Food Compos. Anal. 13, 391-410.

8. Bouton, P. E., Harris, P. V., and Shorthose, W. R. (1975) Change in shear parameters of meat associated with structural change produced by aging, cooking and myofibrillar contraction. J. Food Sci. 40, 1122-1126.

9. Bower, J. A., Craig, J. A., Kropf, D. H., and Tucker, T. J. (1987) Flavor, color, and other characteristics of beef Longissimus muscle heated to seven internal temperatures between $55^{\circ} \mathrm{C}$ and $85^{\circ} \mathrm{C}$. J. Food Sci. 55, 533-536.

10.Buck, E. M., Hickey, A. M., and Rosenau, J. (1979) Lowtemperature air oven VS a water bath for the preparation of rare beef. J. Food Sci. 44, 1602-1605.

11. Choi, Y. S., Jeong, J. Y., Choi, J. H., Lee, M. A., Lee, E. S., Kim, H. Y., Han, D. J., Kim, J. M., and Kim, C. J. (2006) Effects of immersion period after tumbling processing on the quality properties of boiled pork loin with soy sauce. Korean J. Food Cookery Sci. 22, 379-385.

12. Choi, J. H., Jeong, J. Y., Choi, Y. S., Lee, E. S., and Kim, C. J. (2008) The relationship between fat level and quality properties of ground pork patties cooked by microwave energy. Korean J. Food Sci. Ani. Resour. 28, 295-300.

13. Culler, R. D., Parrish, Jr. F. C., Smith, G. C., and Cross, H. R.
(1978) Relationship of myofibril fragmentation index to certain chemical, physical and sensory characteristics of bovine. J. Food Sci. 43, 1177-1180.

14. Deethardt, D. and Tuma, H. J. (1971) Effect of cooking methods on various qualities of pork loin. J. Food Sci. 36, 626-628.

15. Dube, G., Bramblett, V. D., Judge, M. D., and Harrington, R. B. (1972) Physical properties and sulfhydryl content of bovine muscles. J. Food Sci. 37, 23-26.

16. Forrest, J. C., Aberle, E. D., Hedrick, H. B., Judge, M. D., and Merkel, R. A. (1975) Principle of meat science. W.H Freeman and company, San Francisco, pp. 298-305.

17. Godsalve, E. W. (1977) Effect of oven conditions and sample treatment on water loss of dry cooked bovine muscle. $J$. Food Sci. 42, 1325-1330.

18. Herring, H. K., Cassens, R. G., and Briskey, E. J. (1965) Further studies on bovine muscle tenderness as influenced by carcass position, sarcomere length, and fiber diameter. $J$. Food Sci. 30, 1049-1054.

19. Jung, I. C., Moon, Y. H., and Kang, S. J. (2004) Effect of addition of mugwort powder on the physico-chemical and sensory characteristics of boiled pork. Korean J. Food Sci. Ani. Resour. 24, 15-22.

20. Kim, C. J. and Lee, E. S. (2003) Effects of quality grade on the chemical, physical and sensory characteristics of Hanwoo (Korean native cattle) beef. Meat Sci. 63, 397-405.

21. Laakkonen, E., Whllington, G. H., Sherbon, J. W. (1970) Low-temperature, long-time heating of bovine muscle. I. Changes in tenderness, water-binding capacity, $\mathrm{pH}$ and amount of water-soluble components. J. Food Sci. 35, 175177.

22. Lawrie, R. A. (1988) Lawrie's meat science. 6th ed, Woodhead Publishing LTD., Cambridge, pp. 226-228.

23. Leonhardt, M. and Wenk, C. (1997) Animal species and muscle related differences in thiamine and riboflavin contents of Swiss meat. Food Chem. 59, 449-452.

24. Lewis, G. J. and Purslow, P. P. (1989) The strength and stiffness of perimysial connective tissue isolated from cooked beef muscle. Meat Sci. 26, 255-269.

25. Machlik, S. M. and Draudt, H. N. (1963) The effect of heating time and temperature on the shear of beef semitendimosus muscle. J. Food Sci. 28, 711-718.

26. Marsh, B. B., Woodhams, P. R., and Leet, N. G. (1966) Studies in meat tenderness. I. Sensory and objective assessments of tenderness. J. Food Sci. 31, 262-267.

27. Moller, A. J., Vestergaard, T., and Perdersen, W. (1973) Myofibril fragmentation in bovine longissimus dorsi as an index of tenderness. J. Food Sci. 38, 824-825.

28. Montgomery, T. M., Ramsey, C. B., and Lee, R. W. (1977) Microwave and conventional precooking of hot and cold processed pork loins. J. Food Sci. 42, 310-315.

29. Moon, Y. H., Kim, Y. K., Koh, C. W., Hyon, J. S., and Jung, I. C. (2001) Effect of aging period, cooking time and temperature on the textural and sensory characteristics of boiled pork loin. J. Korean Soc. Food Sci. Nutr. 30, 471-476.

30. Moss, M., Holden, J. M., Ono, K., Cross, R., Slover, H., 
Berry, B., Lanza, E., Thompson, R., Wolf, W., Vanderslice, J., Johnson, H., and Stewart, K. (1983) Nutrient composition of fresh retail pork. J. Food Sci. 48, 1767-1771.

31. Obuz, E., Dikeman, M. E., Erickson, L. E., Hunt, M. C., and Herald, T. J. (2003) Predicting temperature profiles to determine degree of doneness for beef biceps femoris and longissimus lumborum steak. Meat Sci. 67, 101-105.

32. Oh, H. S. and Myoung, C. O. (1994) Application of microwave heating to the convenient preparation of moist-heated meats. J. Korean Soc. Food Sci. 10, 357-362.

33. Olson, D. G., Parrish, F. C. Jr., and Stromer, M. H. (1976a) Relationship of myofibril fragmentation index to measures of beef steak tenderness. J. Food Sci. 42, 506-509.

34. Olson, D. G., Parrish, F. C. Jr., and Stromer, M. H. (1976b). Myofibril fragmentation and shear resistance of three bovine muscles during postmortem storage. J. Food Sci. 41, 10361041.

35. Pan, Z. and Singh, P. (2001) Physical and thermal properties of ground beef during cooking. Lebensm-Wiss. U. Technol. 34, 437-444.

36. Park, S. W. and Kwon, S. K. (1998) Sensory characteristics and tenderness of boiled beef by addition of the barks (Morus alba Linne). J. Korean Soc. Food Sci. Nutr. 11, 580-584.

37. Parrish, F. C. Jr., Vandell, C. J., and Culler, R. D. (1979) Effect of maturity and marbling on the myofibril fragmentation index of bovine longissimus muscle. J. Food Sci. 44, 1668-1671.

38. Pearson, A. M. and Dutson, T. R. (1988) Edible meat byproducts. Advances in meat research. Elsevier Science Publishers LTD, NY, Vol. 5, pp.15-45.

39. Pietrasik, Z. and Shand, P. J. (2003) The effect of quantity and timing of brine addition on water binding and textural characteristics of cooked beef rolls. Meat Sci. 65, 771-778.

40. SAS. (1996) SAS/STAT Software for PC. Release 6.11, SAS Institute Inc., Cary, NC, USA.

41. Tajima, M., Ito, T., Arakawa, N., and Parrish, Jr. F. C. (2001) Heat-induced changes of myosin and sarcoplasmic proteins in beef during simmering. Food Chem. Toxicol. 66, 233-237.

42. Voyle, C. A. (1971) Sarcomere length and meat quality. Proceedings 17th European meeting of meat research workers, Bristol, England, pp. 95-97.

(Received 2009.8.24/Revised 2010.2.10/Accepted 2010.2.10) 